\title{
A Statistical Overview of Bibliodiversity in the Latvian Book Market
}

\author{
Elza Ungure ${ }^{1,2}$
}

Published online: 30 January 2022

(C) The Author(s), under exclusive licence to Springer Science+Business Media, LLC, part of Springer Nature 2021

\begin{abstract}
This paper offers a statistical overview of bibliodiversity in the Latvian book market - a small language market in terms of the number of Latvian language users and home for people from varied ethnic and national backgrounds. Diversity of the book output during 1991-2020 is analysed in terms of languages and general categories in which books are published, shares of literary genres in fiction publishing, shares of original and translated fiction titles, languages from which fiction titles are translated, as well as the background of fiction authors who have been translated and published in Latvia.
\end{abstract}

Keywords Bibliodiversity $\cdot$ Rationality $\cdot$ Economic value $\cdot$ Socio-cultural value Small language market

\section{Introduction of Research Aim, Methods, and Theoretical Outlook}

It has been argued that in the twentyfirst-century, book publishers are increasingly operating based on the economic value system instead of cultural and literary value systems. Thereby "the hunt for bestsellers" has become the driving force of many publishers, given that even a few bestsellers can generate the majority of a publisher's annual income [19, p. 1-2]. Consequently, certain titles might have an advantage when what becomes published is decided. Specifically, since statistically, the majority of titles that have become international bestsellers have first been published in English [19, p. 7], when deciding on new projects, publishers operating within the economic value system might be more likely to choose to publish translations from titles in English, which have already done well in other markets, over translations

Elza Ungure

elza.ungure@lnb.lv

1 Collection Management Department, Bibliography Institute, The National Library of Latvia, Riga, Latvia

2 Krājuma veidošanas nodaḷa, Latvijas Nacionālā bibliotēka, Mūkusalas iela 3, Rīga 1423, Latvia 
from other languages as well as original titles by local authors. However, such practice can result in a rather bland, homogenous supply of books, which does not represent various voices or cultural multiversity [7, 13, p. 125, 19, p. 5-9], which, as argued by Susan Hawthorne [7], are the components of bibliodiversity signalling of a healthy and sustainable publishing industry. After all, books are merit goods: they have not only economic value, which is relevant for those within the industry, but also socio-cultural value, which is relevant for societies and cultures [18]. The socio-cultural value can only be achieved by ensuring bibliodiversity, as explained by McCleery and Ramdarshan Bold [13]. They suggest that a distinction can be made between publishing in a country and for a country, where the former is based on economic rationality but the latter in socio-cultural rationality. Publishing for a country means reflecting "cultural nationalism and its literary or historiographical expression" [13, p. 117] to "ensure that a range of cultural and educational needs are met" [13, p. 123].

In this paper, I explore the bibliodiversity of books and brochures (from now on-books) published in Latvia during 1991-2020 through analysis of statistical data gathered and published by the National Library of Latvia (NLL) in the form of a data set of non-aggregated data [11]. The data are based on legal deposits of books published during a calendar year and received by the NLL from publishers (all juridical persons registered in the Republic of Latvia and natural persons residing in Latvia) and legal deposits of books delivered with a year's delay. The statistics include data on books and unconventional or "grey" publications (free of charge books containing publicly available information, such as conference proceedings, public research reports, deposited scientific papers, etc.), regardless of whether books have been assigned an ISBN. Ephemera, atlases, comics, graphic novels, travel guides, thesis summaries, image-based books, such as children's picture books, colouring books, art albums, etc.) are excluded from the analysis. Data on print runs is obtained based on publishing reports submitted by publishers, which provide information on the print runs of books published within the calendar year and additional print runs of any book. However, nationally there are no data on book consumption, sales figures, sales channels, numbers of workers employed in the publishing industry, turnover, and other economic indicators.

I carried out an exploratory data analysis of different indicators available from the data set. The goal was to find out how diverse is the book market in Latvia in terms of languages of publishing, general categories in which books are published, languages from which adult and children's and YA fiction is translated, literary genres, and the proportion of original and translated books in adult and children's and YA fiction. Particular attention was paid to fiction titles since they are leisure goods and a product category generally targeted to the general audience instead of specific professionals, hobbyists, scholars, etc. If publishers are more inclined to publish titles that can be assumed to appeal to larger masses to maximise their profits $[4,17]$, they can adopt certain tried and tested publishing patterns leaving fiction at risk of lacking bibliodiversity. The statistical overview provides data about languages in which books are published, general categories of books in which titles are published, as well as more in-depth analysis of adult and children's and YA fiction, 
including translated fiction, and ends with a summary of conclusions about the state of bibliodiveristy in Latvia.

\section{Background and Outline of the Book Publishing Industry in Latvia}

While Latvia was a Soviet Socialist Republic (1940-1941 and 1944-1990), the book publishing industry was state-owned, highly centralised, and practically impossible for new publishers to enter [5, p. 58, 68]. The industry had to oblige to strict political demands, follow specific standards, including censorship, and depend on the budget allocated by Soviet authorities [15, p. 105, 5, p. 60-61]. Hence, the supply of books did not correspond to the public demand and lacked diversity in terms of voices allowed to reach the public. After the restoration of national independence in the early 1990s, the political, economic, social, and cultural systems transformed, censorship was abandoned, the publishing industry became privatised and regulated by the market forces, and anyone could publish what they wanted if they had access to productive resources $[5, \mathrm{p} .60,68,15$, pp. 116-117]. Despite the scarce productive resources, already from the early 1990s, the number of publishers skyrocketed, representing a large variety of juridical persons as well as individual self-publishers, though the majority of them only released a few books annually [5, p. 60, 68, 15, p. 116-117].

Currently, the book publishing industry in Latvia is vast but concentrated as few relatively large publishing houses dominate the market in terms of the annually published number of titles and size of print runs. Generally, around 15-20 publishers in Latvia publish more than one per cent of the total number of annually published titles, and only one publishes more than ten per cent. The situation is similar in terms of annual print runs, except the biggest publisher is responsible for around 30-40 per cent of the total annual print run. In addition, the largest publishers coexist with many medium, small and micro-publishing houses and individual publishers who generally publish far fewer titles annually and in far smaller print runs. The largest publishing houses also own the largest network of bookstores.

Also, although there is a "linguistic firewall" [13, p. 123] protecting publishers who publish in Latvian, the market is still decreasing as the population size drops for demographic and migration reasons. The population size of Latvia has been declining since the $1990 \mathrm{~s}$, from 2.7 million in 1990 to 1.9 million in 2020 . However, the actual number of inhabitants is speculated to be even smaller due to external migration, which intensified during the global financial crisis. In 2017, $62.3 \%$ of the population reported using Latvian at home while $37.7 \%$-Russian [3]. Hence, international competition is also relevant for the publishing industry in Latvia as the number of Russian users has always been high. Also, since the restoration of national independence, English proficiency has increased as English is a mandatory subject. Therefore, the book market in Latvia, especially in Latvian, is a very small market due to the globally low prevalence of the Latvian language. 
According to data collected by the Federation of European Publishers, the value of the domestic book market in Latvia along with Estonia and Iceland is one of the lowest in the EU, EEA, and EU candidates, amounting to a total of between 0 and 50 million Euros in 2015 [6, p. 8]. The value of the book market is also low when estimated per inhabitant, amounting to between 10 and 25 million Euros in 2015 as in the case also of Estonia, Lithuania, Slovakia, Hungary, Bulgaria, and Greece [6, p. 8]. The net turnover of publishers in Latvia is also among the lowest along with Iceland and Estonia, amounting to between 10 and 25 million Euros in 2015 [6, p. 4]. Latvia, along with Estonia, Lithuania, and Slovenia, is also one of the countries with the lowest number of annually published titles, with 1500-5000 titles published annually during 2010-2015 [6, p. 6]. In the context of the number of inhabitants, however, Latvia ranks higher with the number of annually published titles as there were between 1000 and 1250 titles published per million inhabitants during 2010-2015 as also in Sweden, Lithuania, Netherlands, Belgium, and Bulgaria [6, p. 7].

On average, 2191,57 titles have annually been published in Latvia during 1991-2020. The actual number of annually published titles first surpassed 2000 titles in 1997, neared the 3000 title mark in the 2000s, declined to around 2000 titles during the global financial crisis, and fell below the 2000 title mark for the first time in 23 years during the first year of Covid-19 pandemic in Latvia, in 2020. As in other countries that used to be part of the USSR, the number of annually released book titles has been increasing since the 1990s, but the print runs have continuously decreased in Latvia. The total annual print run has declined from 28,535,000 copies in 1991 to 1,957,369 copies in 2020 . The average print run of a title has also decreased since the 1990s from $23,389,34$ copies per title in 1991 to 1084,41 in 2020 . However, most titles are released in print runs smaller than the average print run, with median print run amounting to 600 copies in 2020, for example.

The decrease in the print run is expected since the variety in supply disperses demand, and the relatively high price of books compared to the purchasing power of consumers also limits the effective demand [14, p. 23]. In addition, niche titles are also generally published in smaller print runs [1, p. 132-133]. Typically, the annual rate of change of print runs corresponds to the general economic climate of Latvia. Some of the most significant increases occur during periods of economic growth, and some of the most significant declines during economic recession or instability. This trend is also experienced in other countries such as Estonia, where print runs decrease in times of financial difficulties and-if the situation does not improve-after a while, the number of titles published drops as well [16]. These metrics are to be considered when discussing the topic of bibliodiversity since the publishing industry "is much affected by the external environment - the political, economic, technological conditions of the state as well as population changes and the situation in education" [12, p. 209]. To put it simply, if there are only so many consumers with only so much money to spend on books, publishers can find themselves in circumstances where they feel the need to supply titles that are not as diverse. The following statistical overview provides grounds to assess how bibliodivesre is the book market in Latvia. 
Table 1 Languages of publishing, $N=65,022$

\begin{tabular}{|c|c|c|c|c|c|c|c|}
\hline & Latvian (\%) & Russian (\%) & English (\%) & Multiple (\%) & German $(\%)$ & $\begin{array}{l}\text { Latgalian } \\
\text { written } \\
(\%)\end{array}$ & $\begin{array}{l}\text { Other } \\
(<0.1 \%) \\
(\%)\end{array}$ \\
\hline 1991 & 62.50 & 33.44 & 1.49 & 0.75 & 0.83 & 0.50 & 0.50 \\
\hline 1992 & 68.34 & 23.40 & 3.52 & 1.44 & 1.65 & 0.86 & 0.79 \\
\hline 1993 & 80.72 & 10.44 & 4.92 & 1.80 & 1.26 & 0.47 & 0.40 \\
\hline 1994 & 82.96 & 10.77 & 3.98 & 1.31 & 0.65 & 0.00 & 0.33 \\
\hline 1995 & 83.33 & 7.97 & 5.86 & 1.34 & 0.82 & 0.26 & 0.41 \\
\hline 1996 & 85.80 & 6.27 & 4.72 & 0.93 & 1.50 & 0.31 & 0.47 \\
\hline 1997 & 85.91 & 6.76 & 4.39 & 1.14 & 1.05 & 0.44 & 0.31 \\
\hline 1998 & 85.34 & 7.95 & 4.39 & 1.33 & 0.59 & 0.16 & 0.24 \\
\hline 1999 & 83.49 & 7.83 & 4.70 & 1.60 & 1.87 & 0.23 & 0.27 \\
\hline 2000 & 81.31 & 8.56 & 5.12 & 2.60 & 1.24 & 0.44 & 0.72 \\
\hline 2001 & 83.61 & 7.49 & 4.81 & 2.32 & 1.04 & 0.44 & 0.28 \\
\hline 2002 & 82.11 & 8.07 & 4.25 & 4.43 & 0.57 & 0.18 & 0.39 \\
\hline 2003 & 81.16 & 7.90 & 4.79 & 3.93 & 1.28 & 0.35 & 0.58 \\
\hline 2004 & 83.75 & 6.44 & 4.40 & 4.00 & 0.71 & 0.24 & 0.47 \\
\hline 2005 & 82.26 & 7.88 & 3.94 & 3.73 & 0.81 & 0.47 & 0.90 \\
\hline 2006 & 84.05 & 7.22 & 3.57 & 3.57 & 0.50 & 0.46 & 0.63 \\
\hline 2007 & 86.42 & 5.64 & 3.77 & 2.97 & 0.59 & 0.22 & 0.40 \\
\hline 2008 & 86.43 & 6.11 & 3.30 & 3.09 & 0.28 & 0.46 & 0.32 \\
\hline 2009 & 84.96 & 8.01 & 3.20 & 2.79 & 0.18 & 0.27 & 0.59 \\
\hline 2010 & 86.40 & 6.82 & 3.07 & 2.57 & 0.35 & 0.25 & 0.54 \\
\hline 2011 & 87.28 & 6.24 & 2.74 & 2.60 & 0.24 & 0.47 & 0.43 \\
\hline 2012 & 84.60 & 7.24 & 3.43 & 3.52 & 0.19 & 0.39 & 0.63 \\
\hline 2013 & 86.00 & 6.37 & 3.93 & 2.76 & 0.23 & 0.27 & 0.45 \\
\hline 2014 & 83.62 & 5.31 & 4.66 & 4.61 & 0.14 & 0.78 & 0.88 \\
\hline 2015 & 83.88 & 5.24 & 5.28 & 4.78 & 0.14 & 0.37 & 0.32 \\
\hline 2016 & 85.22 & 5.03 & 4.44 & 3.89 & 0.32 & 0.50 & 0.59 \\
\hline 2017 & 79.91 & 4.68 & 6.83 & 7.34 & 0.18 & 0.64 & 0.41 \\
\hline 2018 & 76.53 & 5.57 & 6.49 & 10.67 & 0.09 & 0.42 & 0.23 \\
\hline 2019 & 76.08 & 5.53 & 6.38 & 10.91 & 0.14 & 0.48 & 0.48 \\
\hline \multirow[t]{2}{*}{2020} & 80.00 & 6.06 & 4.22 & 9.00 & 0.11 & 0.39 & 0.22 \\
\hline & 82.13 & 8.41 & 4.35 & 3.59 & 0.65 & 0.39 & 0.47 \\
\hline
\end{tabular}

\section{Statistical Overview of Books Published in Latvia, 1991-2020}

\section{Language of Publishing}

Since inhabitants of Latvia are from varied ethnic backgrounds and languages primarily used at home vary as well, first, it is essential to consider how diverse are the books published in Latvia in terms of the language of publication. As shown in Table 1, during 1991-2020, on average, titles in 11,73 languages were published in 
Latvia annually. Since the restoration of national independence, most titles in Latvia are published in Latvian on average amounting to $82,13 \%$ of all titles. Russian was the second most published language until recently, albeit the actual share of titles in Russian decreased significantly in the early 1990s. In the 1990s, there was a large inflow of books published in Russia into the Latvian market [5: 63]. Therefore the competition for the Russian market was much higher than for Latvian and other language markets leading to a decrease in the share of titles published in Russian in Latvia. On average, 8,41\% of all titles during 1991-2020 have been in Russian. While the proportion of titles in Russian has been decreasing, the share of titles in multiple languages has grown. The shares of titles in other languages are overall very small and have not fluctuated much annually. On average, during 1991-2020, $4,35 \%$ of all titles were published in English, 3,59\% in multiple languages, $0,65 \%$ in German, and 0,39\% in Latgalian written language, a dialect of Latvian used in one of the cultural-historical regions of Latvia. While titles are also published in several other languages, on average, the share of each language does not exceed $0,1 \%$. The majority of annually published titles are original and amount to $69,30 \%$, while translations amount to $30,70 \%$ of all titles. The proportion of original titles was only significantly, more than 5,00\% above the average for a few years after the re-established national independence, likely due to authors who previously did not have a chance to get published becoming able to.

\section{General Categories}

Since members of any society have a plethora of varied needs and interests, in assessing bibliodiversity, it is important to look at general categories in which titles are published annually to get a general idea of whether these needs might be met. During the 1990s, along with translated fiction, other categories previously unavailable to readers in Latvia were also in high demand, including memoirs/documentaries as well as history books and esoteric and spiritual literature [5, p. 68, 14, p. 23], which are typically grouped under reference literature and popular science literature categories by the NLL. In recent decades, on the other hand, it can be argued, some of the most popular and commercially or economically successful books allow readers to empathise or identify with authors or literary characters. Hence, fiction and memoir/documentary-type titles are in demand as democratic (as opposed to high-brow) "experience literature" [8, p. 362-363], which can be likened to content on social media platforms and reality TV or documentaries [2, p. 121-122, 8, p. 362-363].

As can be seen in Table 2, from 1991 to 2020, the most published general category of titles is adult fiction, amounting to $21,44 \%$ of annually published titles. The increase in the share of fiction titles was the most significant change in the annual shares of titles published in each general category. In the second half of the 1980s, when Latvia still was the Soviet Socialist Republic, fiction accounted only for approximately 8-10 per cent of annually published titles, only just about a half of which were prose, with only a section of them being translations of popular foreign titles from outside of the USSR [5, p. 58]. The share of adult fiction increased 


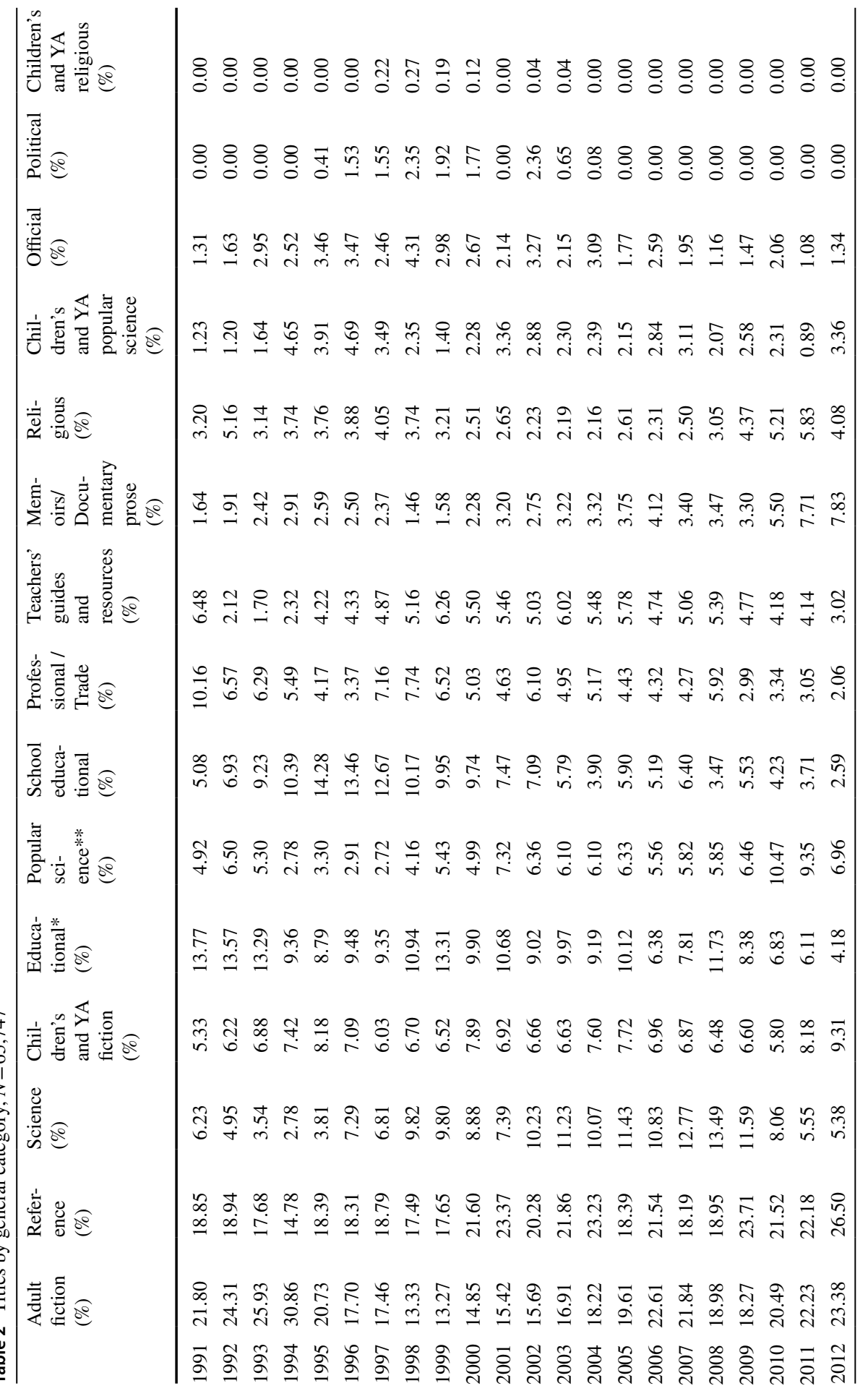




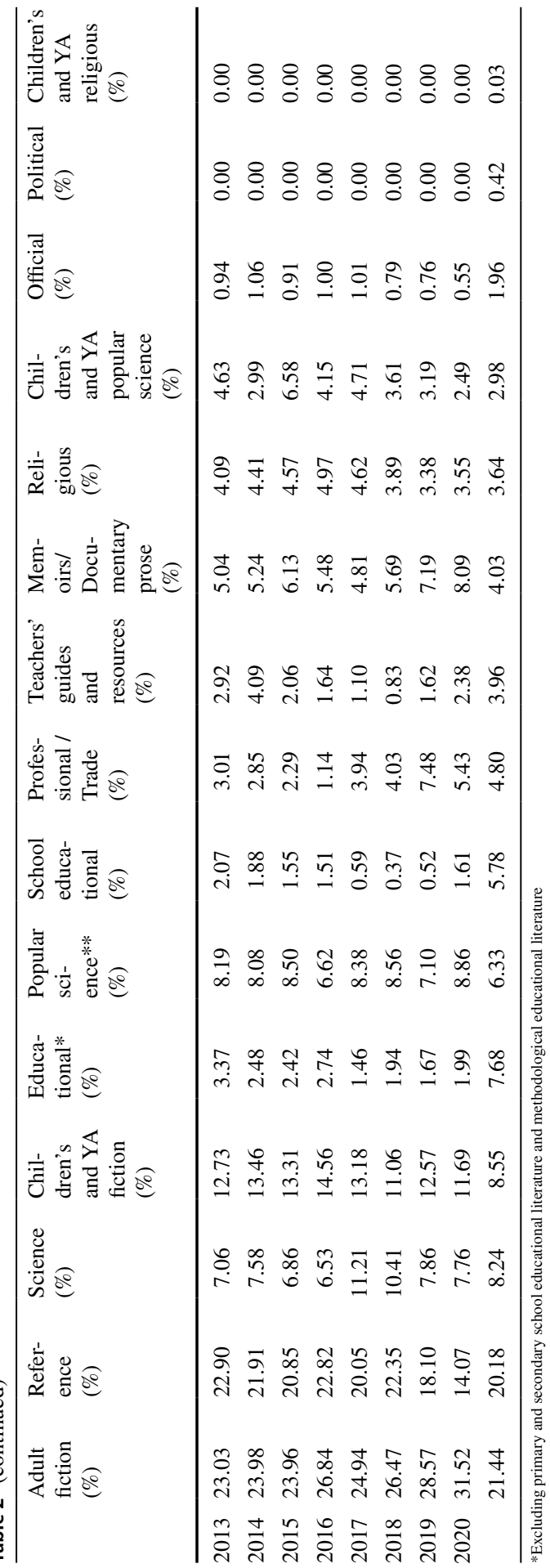


during the first years of regained independence until 1994 when it reached 30,86\%. In subsequent years, the share of adult fiction became smaller, reaching only $13,27 \%$ in 1999. From then, the proportion of adult fiction in all annually published titles gradually began to increase again, having reached 31,52\% in 2020.

Reference literature is the second most published general category on average amounting to $20,18 \%$ of annually published titles. The share of reference literature in annually published titles has not changed as much as in adult fiction; it generally represents between $17,00 \%$ and $24,00 \%$ of titles. Only in 2012 was the share of reference literature higher-26,50\% — as reference literature providing practical guidance and advice proved to sell better than other categories in the aftermath of the global financial crisis [20]. In 2020, on the other hand, the share of reference literature was the lowest it had ever been-14,07\%-likely in response to the Covid-19 pandemic. However, specific reasons should be investigated with qualitative methods.

Titles of other general categories constitute significantly smaller shares, amounting to less than $10 \%$ of the total number of annually published titles. These include science (on average $8,24 \%$ of titles), children's and YA fiction $(8,55 \%)$, educational $(7,68 \%)$, popular science $(6,33 \%)$, school educational $(5,78 \%)$, professional/trade $(4,80 \%)$, memoirs/documentary prose $(4,03 \%)$, school methodological $(3,96 \%)$, religious $(3,64 \%)$, children's and YA popular science $(2,98 \%)$, official $(1,96 \%)$, political (0,42\% (category only used for 1995-2004)), and children's and YA religious literature $(0,03 \%$ (category only used for 1997-2003)).

\section{Fiction}

Much like elsewhere in the Western world, the most published literary genre of adult fiction in Latvia is prose, representing $67,10 \%$ of titles. The second most published genre is poetry, on average amounting to $25,05 \%$ of titles, which is a characteristic of Latvian literature that carries over from the Soviet period [9] as at the time due to form and figures of expression, poetry allowed voicing more diverse and subversive ideas through subtext. For the past 30 years, the share of adult prose has even decreased while the share of adult poetry increased. Other literary genres in Latvia are less common in annual publishing outputs. On average, mixed genres amount to $5,07 \%$, folklore amounts to $1,82 \%$, and plays to $0,96 \%$ of adult fiction titles. In the case of other genres, the shares have remained relatively unchanged, though, since the mid-1990s, the share of mixed genres has increased slightly.

Children's and YA fiction in Latvia is the fourth most published general category of books. However, on average, it represents only $8,55 \%$ of all annually published titles. Similar to adult fiction, the most published genre of children's and YA fiction is prose, which on average amounts to $72,87 \%$ of titles. Shares of other literary genres are typically smaller: on average, $14,35 \%$ of children's and YA fiction titles are poetry, $8,20 \%$ are folklore, $2,99 \%$ are mixed genres, and 1,62\% plays. Over the 30 years, the share of children's and YA prose shows has increased, and the share of the folklore declined, while shares of other genres, albeit changing from year to year, overall are relatively stable. 
Since the 1990s, to succeed in competition, many publishers focused on finding translators to publish popular foreign literature lacking during the Soviet period to Latvian [5, p. 64, 67-68]. Overall, translated prose-romance, detective, and historical novels especially - were in demand along with original poetry by already popular Latvian poets [5, p. 68, 14, p. 23]. From original fiction, poetry by already popular Latvian poets was the most in-demand [5, p. 68, 14, p. 23]. While the trend was similar in Estonia in that publishers preferred translated fiction to original, they reportedly were particularly reluctant to publish short stories and poetry by local authors believing they promised little commercial success [12, p. 215-216]. Reportedly, in Slovenia, a similarly small language market, people are four times more likely to choose translated foreign titles over original ones by local authors [2, p. 121]. Indeed, the pursuit of translated fiction is likely a safer choice from the standpoint of economic rationality as typically, the titles that get translated in many languages are in some way "the best the world has to offer" [2, p. 121] in a particular genre. Hence, in the early years of regained independence in Latvia and other post-Soviet countries, bibliodiversity was hindered by a focus on economic value and rationality. However, this trend has been countered to a degree with the state's introduction of grants and other support mechanisms, which were created to promote publishing categories of books that were otherwise lacking in local languages [12, p. 215-216]. In Latvia, this task is carried out by VKKF, which was established in 1998.

Overall, the proportion of original and translated adult fiction is quite similar in Latvia. During 1991-2020, 53,77\% of adult fiction titles have been original while $46,23 \%$ - translated. Only in the 1990s, the share of translated adult fiction increased and remained larger than the share of original adult fiction until 1999. Since then, the share of original adult fiction has been growing and has typically been slightly larger than the share of translated adult fiction, except in 2005 and 2007 when translated adult fiction was published somewhat more than original. A review of the proportion of original and translated adult fiction by literary genres, on the other hand, suggests a different pattern. As shown in Table 3, on average, the most significant shares of adult fiction are formed by translated prose amounting to $43,40 \%$ of adult fiction, original prose amounting to $23,70 \%$, and original poetry amounting to $22,91 \%$. On average, original mixed genres amount to $4,29 \%$, translated poetry to $2,14 \%$, and original folklore to $1,41 \%$ of adult fiction, while other original and translated literary genres constitute less than $1,00 \%$ of adult fiction. A look at the trends in original and translated adult fiction by literary genres suggests that overall the share of translated prose shows a trend of decline. On the other hand, the share of original prose and original mixed genres (although the latter's share is relatively small) shows a mild trend of increase. Still, the share of original poetry exhibits a strong trend of growth.

As opposed to adult fiction, while the proportion of original and translated children's and YA fiction is similar, generally, the majority of children's and YA fiction is translated on average amounting to $57,52 \%$ of titles. In comparison, original fiction amounts to $42,48 \%$. Similarly, a breakdown of the proportion of original and translated children's and YA fiction by literary genres (see Table 4) suggests that the most significant shares of titles are formed by translated prose on average amounting to $51,97 \%$ of titles, original prose amounting to $20,89 \%$, and original poetry 


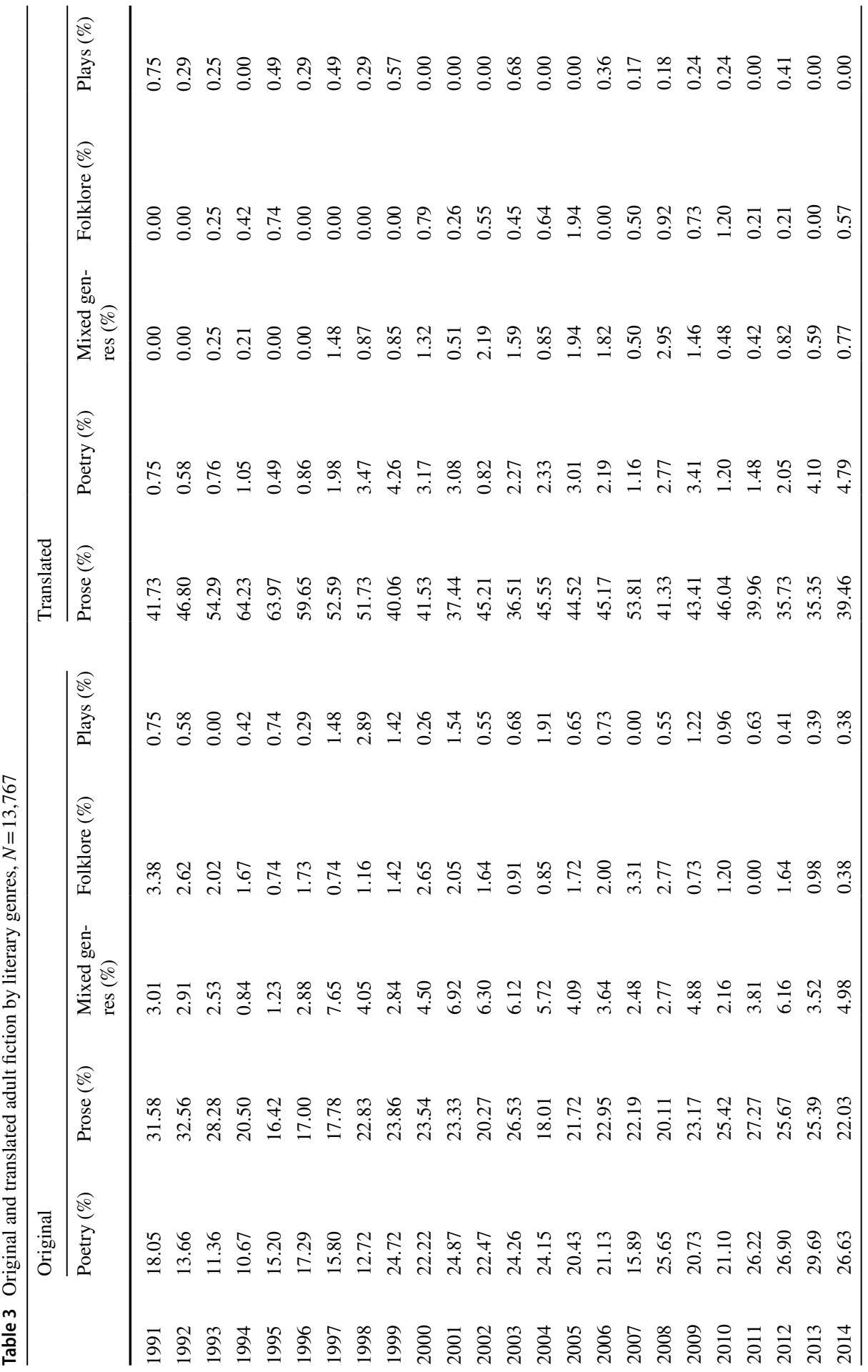




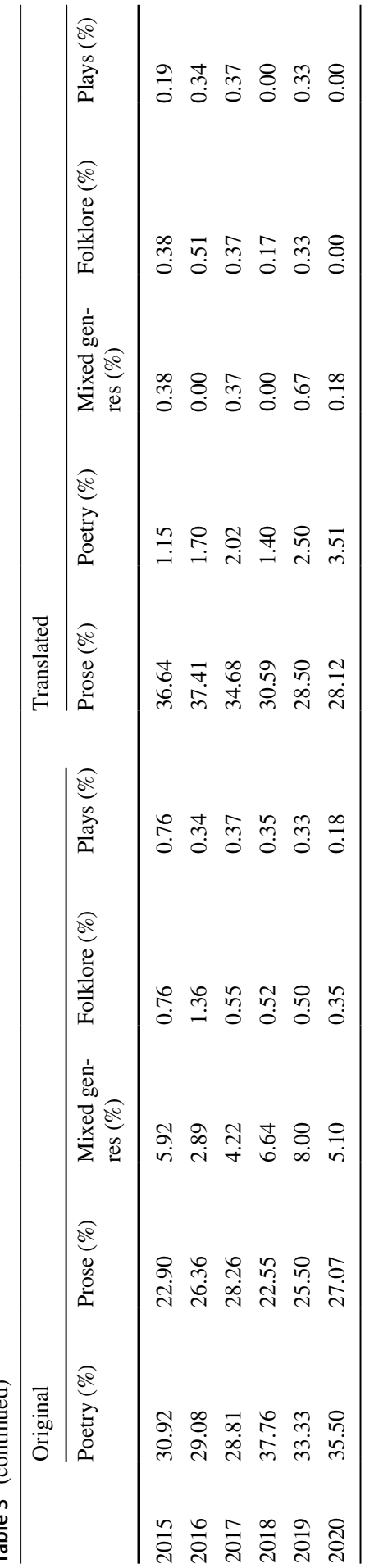




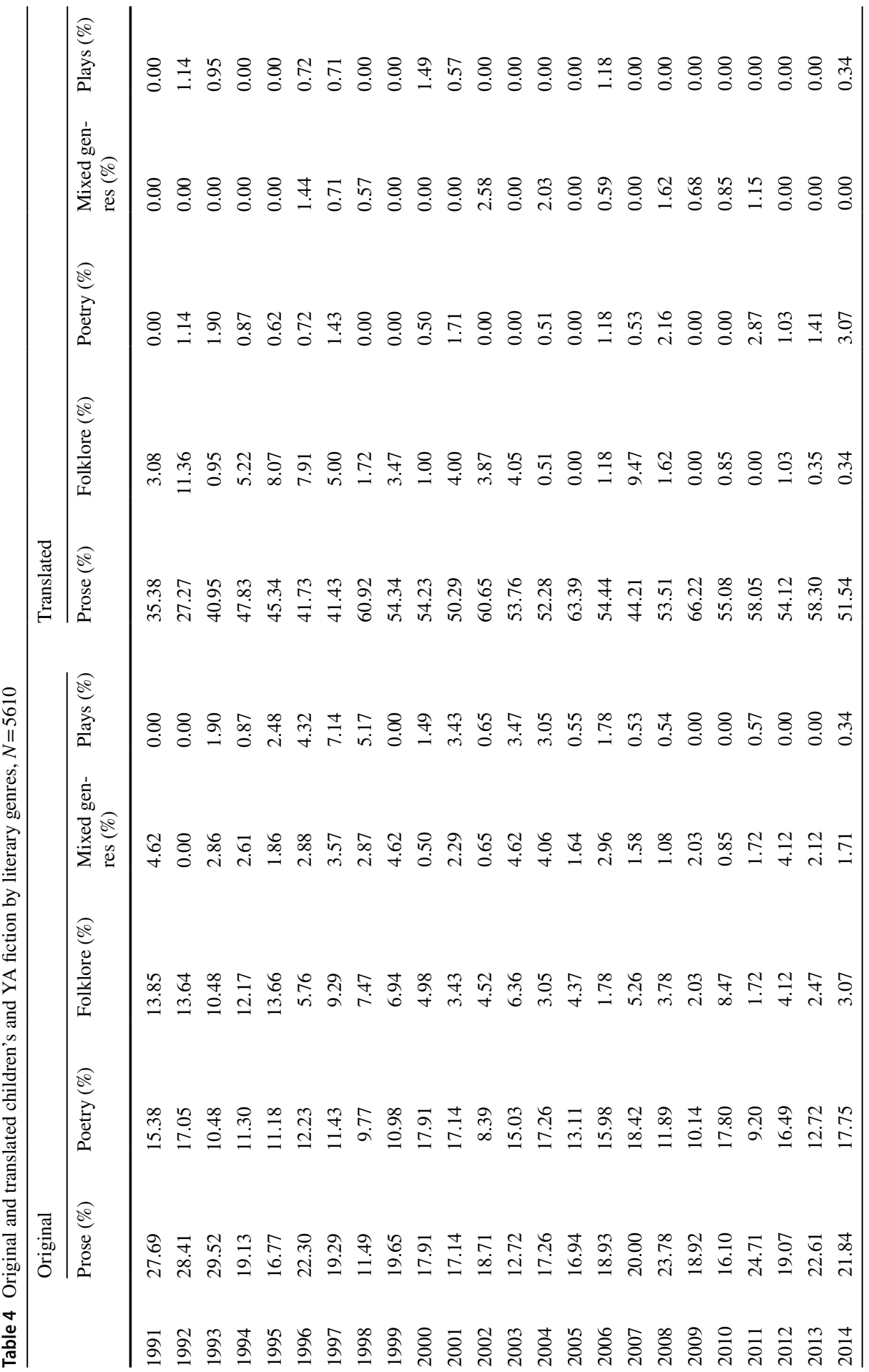




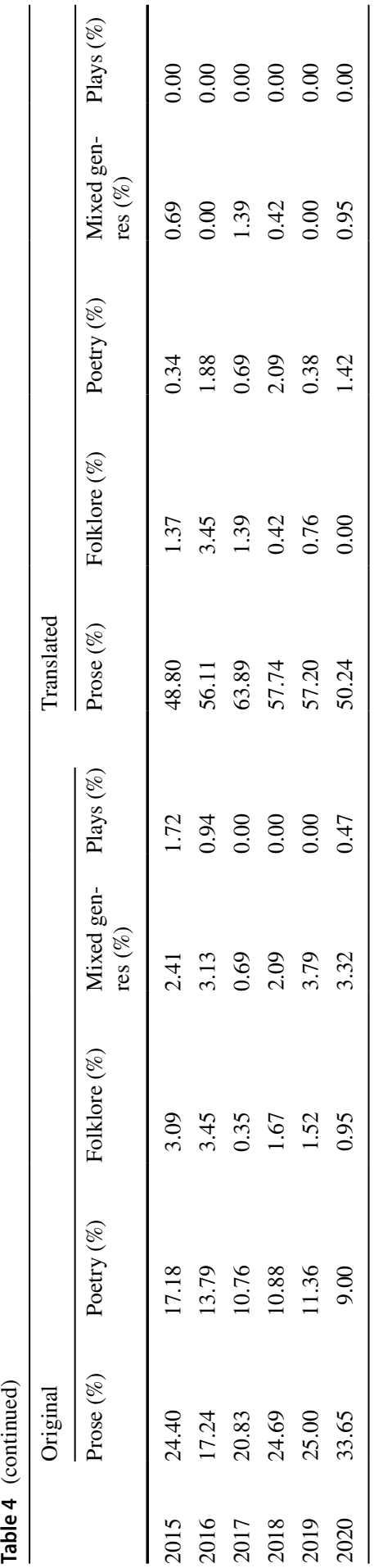


amounting to $13,40 \%$. On the other hand, original folklore on average amounts to $5,46 \%$ of the children's and YA fiction, original mixed genres to $2,44 \%$, translated folklore to $2,75 \%$, and original plays to $1,38 \%$, while other translated literary genres on the average amount for less than 1,00\% of children's and YA fiction titles. Analysis of trends in original and translated children's and YA fiction by literary genres suggests that the share of translated prose exhibits a trend of decline, while the shares of original poetry and original mixed genres - a trend of increase. Shares of other original and translated literary genres fluctuate yearly but can be characterised as stable overall. It has been noted by publishers of children's and YA books [10] that in Latvia, there is a lack of writers for children and YAs, especially in the case of prose, which the statistics confirm.

\section{Translated Fiction}

Overall, during 1991-2020, on average, adult fiction titles translated from 19,4 languages are published annually. The majority of translated adult fiction titles are translated from English, German, French, and Russian. Meanwhile, the leading source languages are different when considering each literary genre on its own (see Table 5). The majority of mixed genres titles are translated from titles in multiple languages, Latvian ${ }^{1}$, and English. The majority of plays are translated from German, Swedish, Ancient Greek, Latvian, English, Norwegian, and Polish. Most poetry is translated from Latvian, Russian, English, German, Estonian, titles in multiple languages, and French. The majority of folklore is translated from titles in multiple languages, in Latvian, and Estonian. Finally, the majority of prose is translated from English, German, French, and Russian. Throughout the 1990s, the shares of adult fiction translated from French and German were relatively high, representing more than $10 \%$ of the translated fiction. Since then, the share-while still typically being above the 5\% mark annually - has decreased. In the case of translations from other languages, while the shares of translations from each language fluctuate in size year from year, no particular trends emerge from the data.

Speaking of translated children's and YA fiction, on average, children's and YA fiction titles translated from 13,13 languages are published annually. The majority of titles are translated from English, German, French, and Italian. Like in the case of translated adult fiction, languages from which children's and YA fiction titles are translated differ from the overall trend when looking at literary genres and vary from genre to genre (see Table 6). The majority of mixed genres titles are translated from English, multiple languages, and German. The majority of plays are translated from English, Norwegian, and Latvian. Most poetry is translated from English, German, Russian, Japanese, Latvian, and Swedish. Most folklore is translated from English, Russian, Italian, Latvian, multiple languages, Polish, and Spanish. The majority of prose is translated from English, German, French, and Italian. The share of children's and YA fiction translations from Italian increased during the 1990s, peaked

\footnotetext{
1 Adult as well as children's and YA fiction in Latvian typically gets translated to Russian, English, and titles in multiple languages.
} 


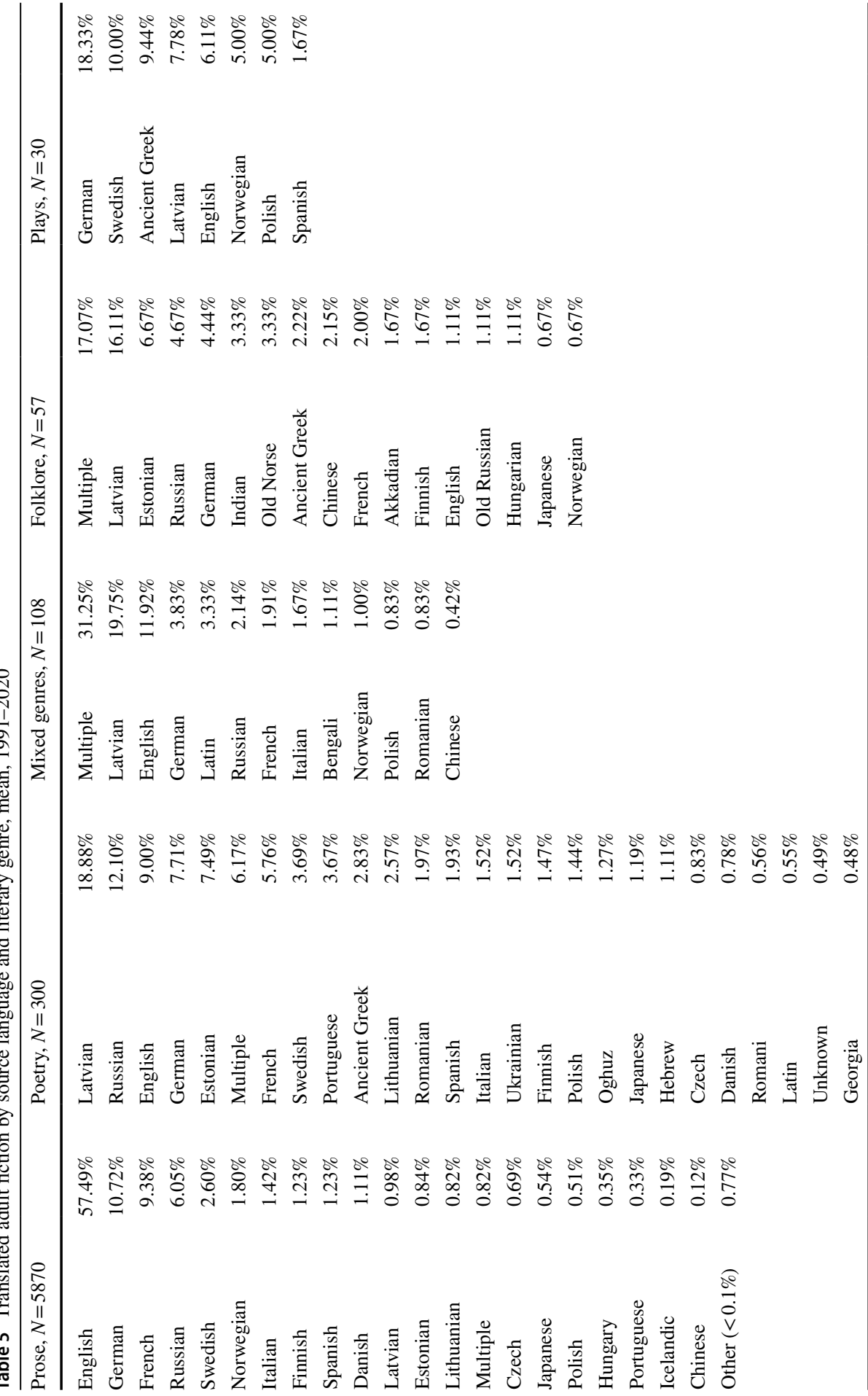




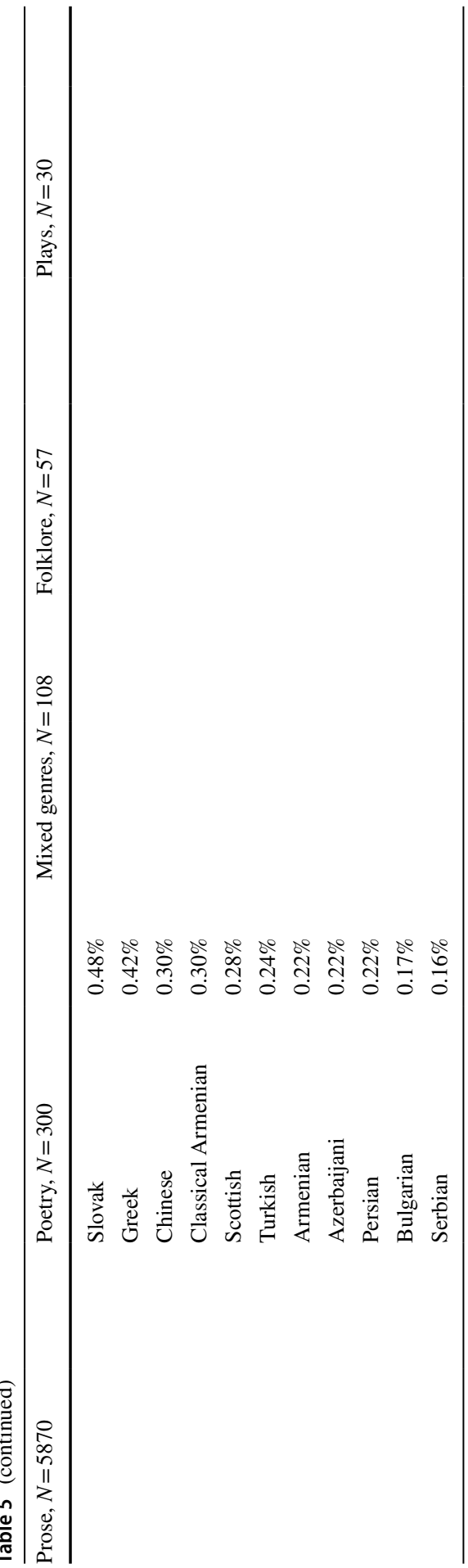


Table 6 Translated children's and YA fiction by source language and literary genre, mean, 1991-2020

\begin{tabular}{|c|c|c|c|c|c|c|c|c|c|}
\hline \multicolumn{2}{|c|}{ Prose, $N=2997$} & \multicolumn{2}{|c|}{ Poetry, $N=58$} & \multicolumn{2}{|c|}{ Folklore, $N=132$} & \multicolumn{2}{|c|}{$\begin{array}{l}\text { Mixed genres, } \\
N=29\end{array}$} & \multicolumn{2}{|c|}{ Plays, $N=11$} \\
\hline English & $51.53 \%$ & English & $18.31 \%$ & English & $19.71 \%$ & English & $20.83 \%$ & English & $9.44 \%$ \\
\hline German & $14.80 \%$ & German & $16.06 \%$ & Russian & $18.44 \%$ & Multiple & $11.11 \%$ & $\begin{array}{c}\text { Norwe- } \\
\text { gian }\end{array}$ & $6.67 \%$ \\
\hline French & $5.98 \%$ & Russian & $8.59 \%$ & Italian & $9.68 \%$ & German & $9.17 \%$ & Latvian & $5.00 \%$ \\
\hline Italian & $5.21 \%$ & Japanese & $6.67 \%$ & Latvian & $9.26 \%$ & Czech & $3.33 \%$ & German & $4.44 \%$ \\
\hline Swedish & $4.69 \%$ & Latvian & $6.67 \%$ & Multiple & $7.20 \%$ & French & $1.11 \%$ & Russian & $1.11 \%$ \\
\hline Russian & $3.28 \%$ & Swedish & $5.00 \%$ & Polish & $6.67 \%$ & Russian & $1.11 \%$ & & \\
\hline Spanish & $2.13 \%$ & Romani & $3.33 \%$ & Spanish & $6.15 \%$ & & & & \\
\hline Estonian & $1.79 \%$ & Multiple & $2.50 \%$ & German & $3.37 \%$ & & & & \\
\hline Lithuanian & $1.37 \%$ & Czech & $1.94 \%$ & Dutch & $1.67 \%$ & & & & \\
\hline Danish & $1.36 \%$ & Italian & $1.67 \%$ & Japanese & $0.59 \%$ & & & & \\
\hline Finnish & $1.13 \%$ & Estonian & $1.48 \%$ & Danish & $0.56 \%$ & & & & \\
\hline Latvian & $1.06 \%$ & Finnish & $1.11 \%$ & Bulgarian & $0.56 \%$ & & & & \\
\hline Polish & $1.05 \%$ & & & Ukrainian & $0.48 \%$ & & & & \\
\hline Norwegian & $1.04 \%$ & & & Arabic & $0.33 \%$ & & & & \\
\hline Multiple & $0.83 \%$ & & & French & $0.33 \%$ & & & & \\
\hline Czech & $0.74 \%$ & & & Dutch & $0.30 \%$ & & & & \\
\hline Dutch & $0.56 \%$ & & & Slovak & $0.30 \%$ & & & & \\
\hline Hungarian & $0.31 \%$ & & & Finnish & $0.30 \%$ & & & & \\
\hline Turkish & $0.19 \%$ & & & Evenki & $0.26 \%$ & & & & \\
\hline Belarusian & $0.14 \%$ & & & $\begin{array}{l}\text { Norwe- } \\
\text { gian }\end{array}$ & $0.26 \%$ & & & & \\
\hline Catalan & $0.13 \%$ & & & Swedish & $0.26 \%$ & & & & \\
\hline Ukrainian & $0.11 \%$ & & & & & & & & \\
\hline Slovenian & $0.11 \%$ & & & & & & & & \\
\hline $\begin{array}{l}\text { Other } \\
(<0.1 \%)\end{array}$ & $0.44 \%$ & & & & & & & & \\
\hline
\end{tabular}

in 1996-1997, and remained above the 5\% mark until 2014. Since then, except for 2007 and 2016, the share of translations from Italian has annually represented less than $5 \%$ of the translated fiction. No other clear trends are visible in data about translations from other languages. Meanwhile, when discussing bibliodiversity, not only source languages of translated fiction must be considered and-perhaps even especially_backgrounds of translated authors.

During 1991-2020, adult fiction titles by authors from 29,13 ethnic and national backgrounds are published annually. As can be seen in Table 7, the majority of translated adult fiction is by authors who are American, English, German, French, and Russian. Most mixed genres translated titles are by multiple authors from varied backgrounds, Latvian authors, and Russian authors. The majority of translated plays are by authors who are German, Swedish, Ancient Greek, Latvian, English, Norwegian, and Polish. Most translated poetry is by Latvian, Russian, Estonian authors, 


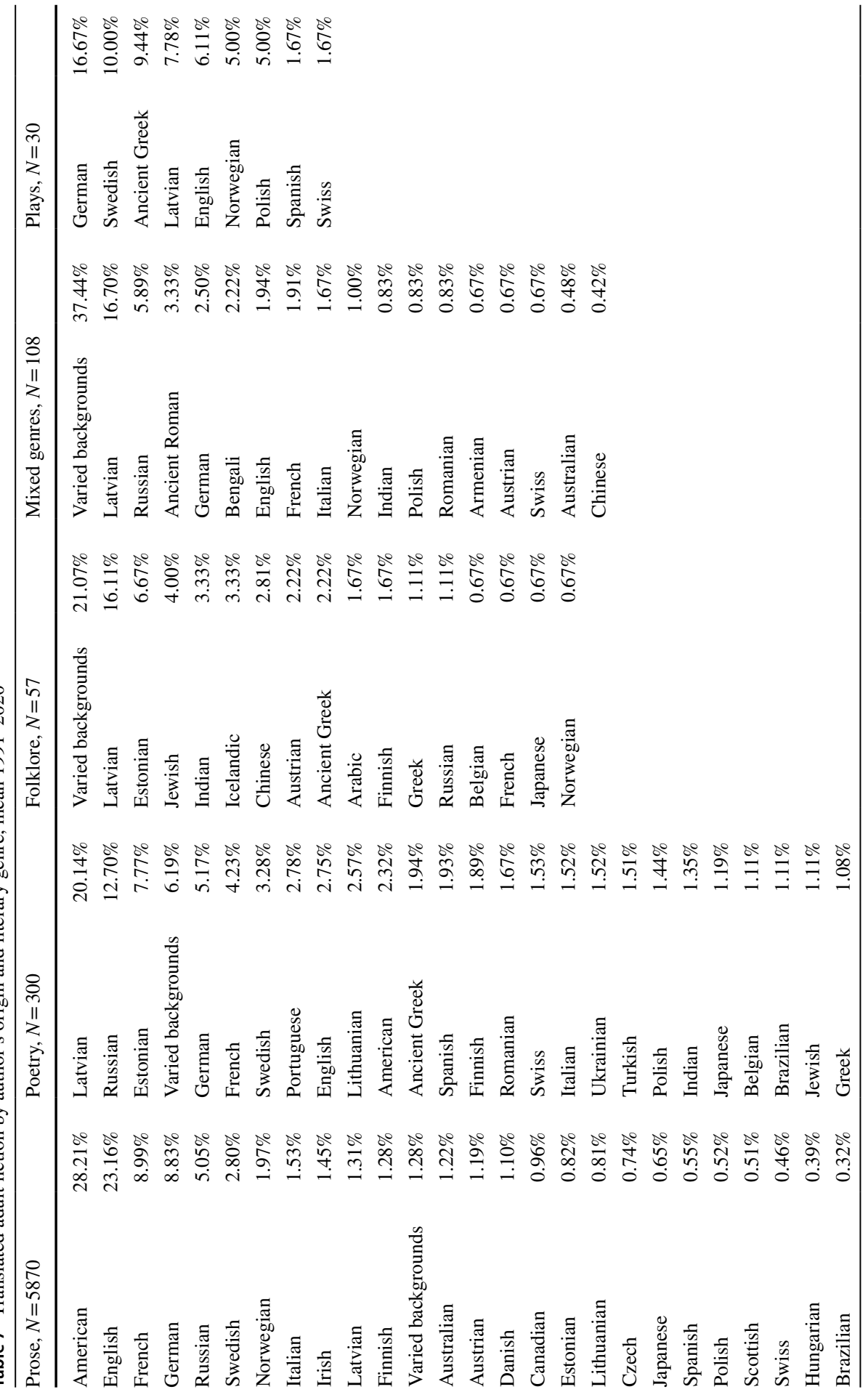




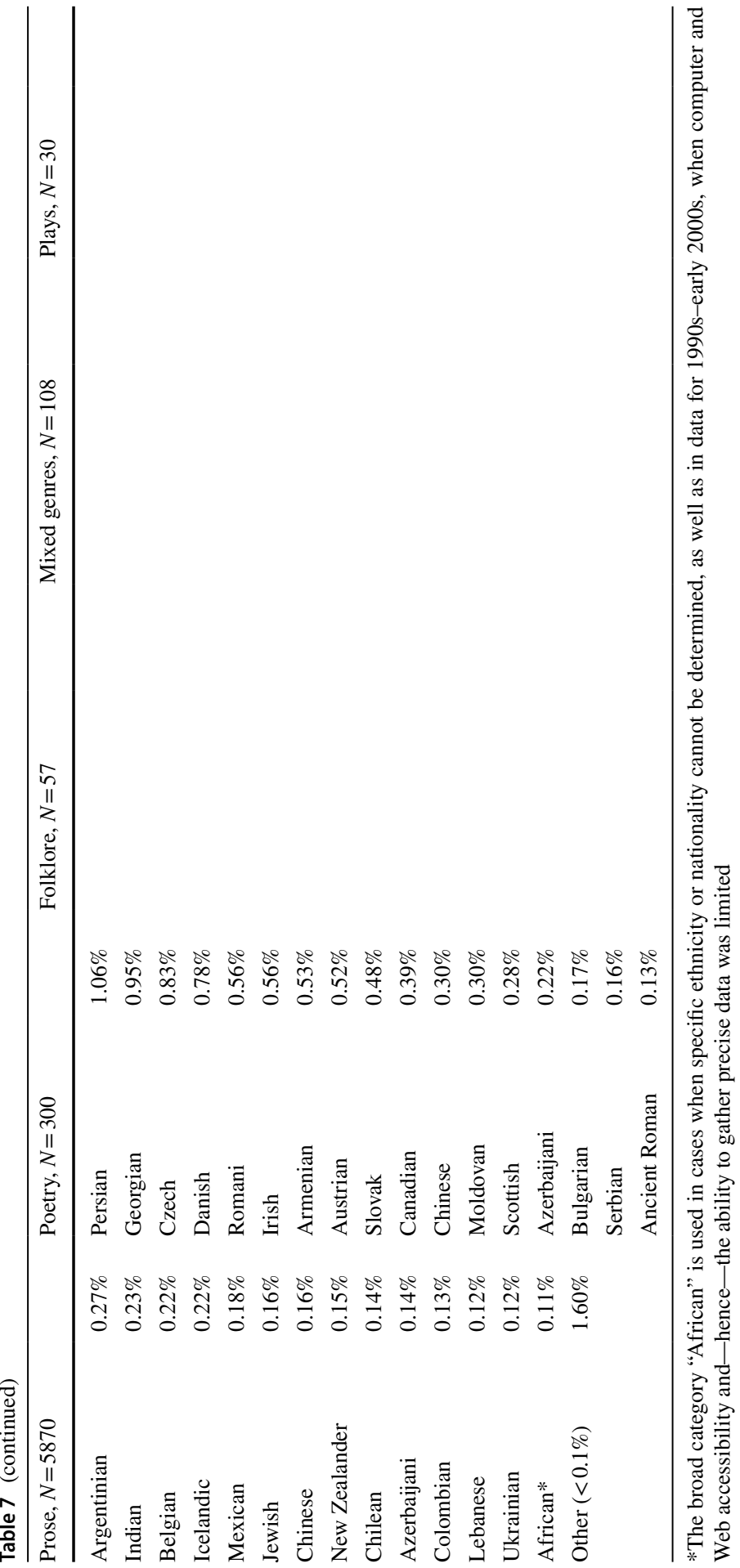


authors from various backgrounds, and German authors. The majority of translated folklore is by multiple ethnic groups, Latvian, and Estonian. The majority of translated adult prose is by authors who are American, English, French, German, and Russian. Shares of French and German fiction were high-representing more than $10 \%$ of translated adult fiction-until the mid-1990s. Since then, the shares have decreased and typically represent just above $5 \%$ of annually published adult fiction translations. Since 2011, the share of Swedish fiction translations has increased and represents around $5 \%$ of translated adult fiction each year, with the globally growing popularity of crime novels from the Nordic region.

Meanwhile, on average, children's and YA fiction titles by authors from 18 different ethnic and national backgrounds are published annually. The majority of translated children's and YA fiction are by authors who are English, American, German, and Italian (Table 8). Most translated mixed genres titles are by multiple authors from varied backgrounds and English and German authors. The majority of translated plays are by authors who are Norwegian, English, and Latvian. Most translated poetry is by German, English, Russian, Japanese, Latvian, American, and Swedish authors. The majority of translated folklore is by varied ethnic groups, Latvian, English, Italian, Russian, and Spanish. And, similarly, also the majority of translated prose is by English, American, German, French, and Italian authors. The share of translated children's and YA fiction by German authors-although still among the highest annually - has become smaller during the past decade. Similarly, the share of French fiction has only exceeded the 5\% mark once during the past decade. Shares of translations of fiction by authors with other nationalities and ethnicities fluctuate year by year but do not exhibit any clear trends.

\section{Conclusion}

The languages in which books are published in Latvia, for the most part, reflect the ethnic composition of Latvia, with titles in Latvian and Russian being the most published. Only titles in English present a different case in this sense. English is considered the lingua franca and is commonly used to communicate scientific findings and reach a broader array of fiction readers. Titles in other languages are rarer but still get published, providing at least some content in native-tongue for other ethnic minorities residing in Latvia. From the perspective of bibliodiversity, it is positive that most titles annually published in Latvia are original titles. And although adult fiction and reference literature constitute by far the most significant shares of annually published titles, there is also a steady supply of titles from other general categories to supply diverse needs and demand. The annual output of literary genres of fiction is also quite diverse. Although prose is the most published genre in the case of adult and children's and YA fiction, the share of poetry is also relatively high, the share of mixed genres is increasing in the case of adult fiction, and some titles of plays and folklore get published each year.

The fact that the shares of original and translated adult and children's and YA fiction are pretty similar is not a source of concern in terms of bibliodiversity as translations of works of authors from different backgrounds can benefit diversity 


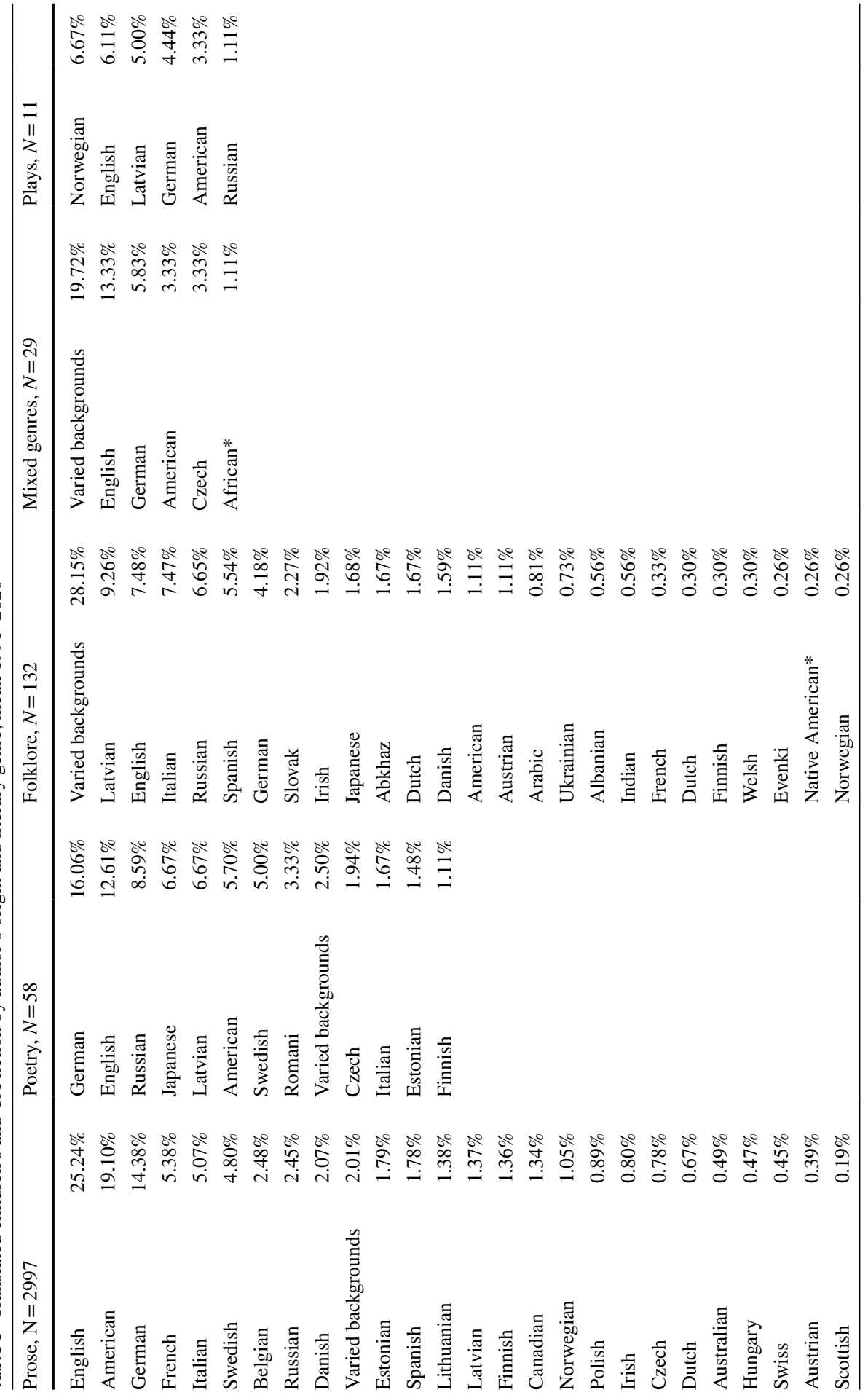




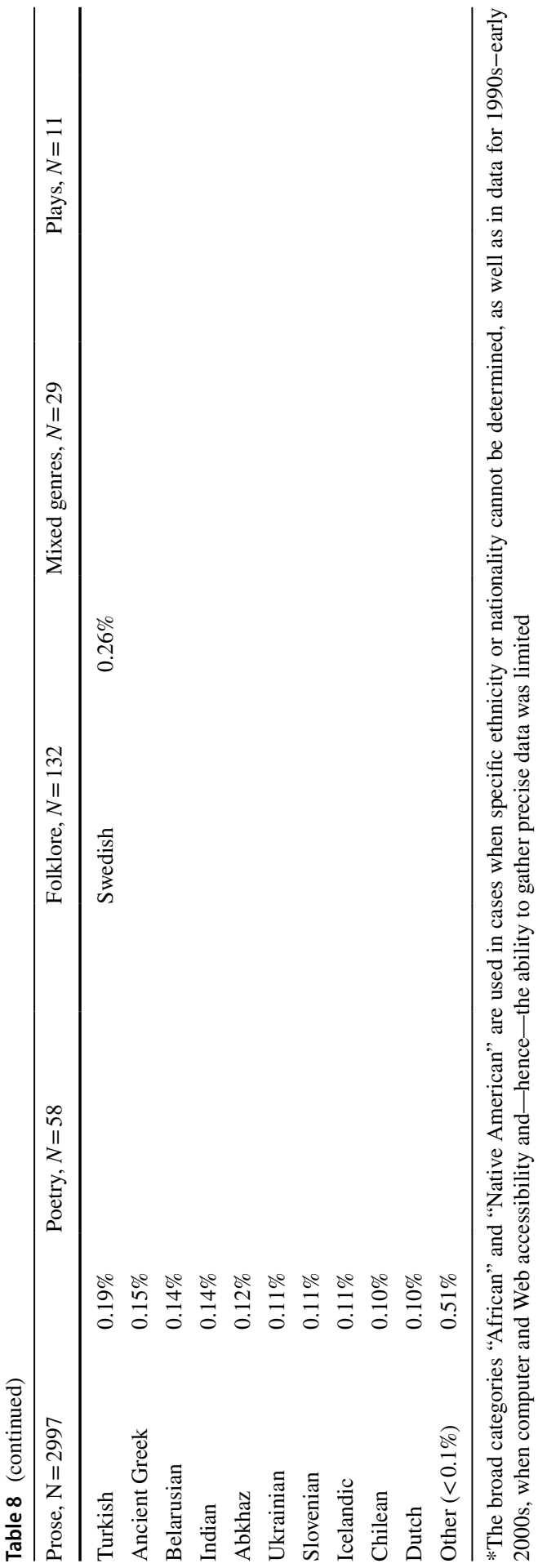


while local authors still get represented. It is also not a concern that the vast majority of translated adult fiction and children's and YA fiction is translated from the largest languages and languages used in countries among the globally largest book markets-English, German, French, Italian -, and Russian. After all, ensuring direct translations from smaller languages to smaller languages is not always possible. It is a source of concern, however, that the vast majority of translated adult and children's and YA fiction titles are by authors who are American, English, German, French, Italian, and Russian. If authors from bigger book markets, bigger countries, and ethnic groups get translated predominantly, the representation of diversity and the support available for a range of cultural, social, and educational needs is limited. As the data show, this is especially problematic in the case of prose, which typically caters to the masses, while more niche genres-poetry, mixed genres, plays, and folklore-appear to be more diverse and represent a wider variety of different voices from different backgrounds. Meanwhile, the shares of translated niche literary genres of adult and children's and YA fiction are generally much smaller than original works. These data suggest that titles from niche literary genres published in Latvia might not be as diverse as they could be had more translations-especially translations of authors with many different backgrounds-been published.

In conclusion, the statistical overview shows that the book market is quite diverse in terms of the overall number of languages of publication, general categories in which books are published, languages from which adult and children's and YA fiction is translated, literary genres of fiction published, as well as the proportion of original and translated books in adult and children's and YA fiction. On the other hand, there are also grounds for concern. We see a pattern of translated fiction lacking diversity of voices since the vast majority of translated titles are by authors from bigger book markets, bigger countries, and ethnic groups. Therefore, future research would be required to determine what mechanisms might facilitate more diverse representations and balance economic and socio-cultural rationality. A more in-depth analysis of topics and themes covered by published titles would also be beneficial to learn about how diverse the book output is in this sense.

Acknowledgements This research was funded by the Latvian Council of Science, project "Latvian Memory Institution Data in the Digital Space: Connecting cultural heritage", project no. lzp-2019/1-0365.

\section{References}

1. Bradley J, Fulton B, Helm M. Self-published books: An empirical "Snapshot." Library Quart Inform Commun Policy. 2012;82(2):107-40.

2. Blatnik A. Translated Literature in Contemporary Slovenia. Knygotyra. 2020;75:114-23.

3. Centrālā statistikas pārvalde. $60,8 \%$ Latvijas iedzīvotāju dzimtā valoda ir latviešu. 2019. https:// www.csb.gov.lv/lv/statistika/statistikas-temas/iedzivotaji/meklet-tema/2747-608-latvijas-iedzi votaju-dzimta-valoda-ir-latviesu.

4. Cutler R. Ingram and Independent Publishing in Holley R.P. Self-Publishing and Collection Development. West Lafayette: Purdue University Press. 2015:83-101.

5. Dreimane J. Authors, publishers and readers of popular literature in Latvia in the Late 1980s and Early 1990s. Interlitteraria. 2015;20(2):56-70. 
6. Federation of European Publishers. The Book Sector in Europe: Facts and Figures. Ixelles: Belgium. 2017.

7. Hawthorne S. Bibliodiversity: A Manifesto for Independent Publishing. North Melbourne, Victoria: Spinifex Press; 2014.

8. Kõvamees A. Mapping the Estonian literature of the selfie-era. Interlitteraria. 2019;24(2):354-65.

9. Krauja V. Kad dzeja bija brīvības vēstnese. Kur tagad pūlis pie Raiņa?. LA.lv. 2017. https://www.la. lv/kad-dzeja-bija-brivibas-vestnese.

10. Kusiņa-Šulce L. Bērnu grāmatās—arī nāve, feminisms un klimata problēmas. 2019. Gada tendences bērnu literatūrā. LA.lv. 2019. https://www.la.lv/bernu-prozas-uzplaukumu-gaidot.

11. Latvijas Nacionālā bibliotēka. Datu masīvs pētniecībai par izdevējdarbību Latvijā. N.d. https://dom. lndb.lv/data/obj/file/30604437.xlsx

12. Lott M, Möldre A. The book policy in a democratic society: the case of Estonia. Knygotyra. 2005;2005(44):209-19.

13. McCleery, A., Ramdarshan Bold, M. 'What is my country?': Supporting Small Nation Publishing'. J Irish Scottish Stud. 2012;6(1):115-32.

14. Möldre A. Publishing and Book Distribution in Estonia in 1940-2000: Abstract. Tallinn: Tallinn University; 2005.

15. Möldre A. The book publishing system in estonia during the Soviet rule in 1944-1991. Knygotyra. 2006;47:105-21.

16. Möldre A. Estonian publishing sector at the turn of the 20th and 21st centuries: emergence of e-book market. Knygotyra. 2014;62:94-115.

17. Ramdarshan BM. An, "Accidental Profession": Small Press Publishing in the Pacific Northwest. Publ Res Q. 2016;32:84-102.

18. von Rimscha MB, Putzig S. From book culture to amazon consumerism: does the digitization of the book industry lead to commercialisation? Publ Res Q. 2013;29:318-35.

19. Rønning H, Slaatta T. Marketers, publishers, editors: Trends in international publishing. Media Cult Soc. 2011;33(7):1-12.

20. Volka A. No reālā patveras grāmatās. Diena. 2009. https://www.diena.lv/raksts/pasaule/krievija/noreala-patveras-gramatas-13832463.

Publisher's Note Springer Nature remains neutral with regard to jurisdictional claims in published maps and institutional affiliations. 